\title{
E-Service Quality and its Effect on Consumers' Perceptions Trust
}

\author{
${ }^{1}$ Mohammad Al-Nasser, ${ }^{1}$ Rushami Zien Yusoff, ${ }^{2}$ Rabiul Islam and ${ }^{1}$ Abdullah ALNasser \\ ${ }^{1}$ School of Business Management, College of Business, University Utara Malaysia, Malaysia \\ ${ }^{2}$ School of Economics, Finance and Banking, College of Business, University Utara Malaysia, Malaysia
}

Received 2013-12-12, Revised 2013-12-29; Accepted 2013-12-31

\begin{abstract}
E-service quality measurement in online shopping has been receiving increasing attention currently and as a result, many studies have tried to highlight major dimensions of e-service quality linked with online environment. Excellent e-service quality is an important matter for online vendor. It is the factor that will enable them to attract more online customers. The aim of the study is to determine e-service quality and its effect on consumers' perceptions of trust. A quantitative research design was adopted to collect data. Multiple regression analysis method was used to conduct this study. The findings of the study will contribute to both theory and practice. The results of this study have important contributions and implications for practitioners and policy-makers. This study contributed to the field of service quality expectations relationship with online shopping in the context of developing countries The findings also revealed that service quality was relatively significant in its impact on consumer trust in online shopping, proving the proposed positive direct impact of perceived service quality upon customer trust.
\end{abstract}

Keywords: E-service Quality, Consumer Perception, Risk, Trust, Attitude

\section{INTRODUCTION}

Electronic service quality has a strategic implication for business attempting to deal with customers in the electronic marketplace. Based on the study by Zeithaml et al. (2000), service quality delivery online is an important strategy for success. It is even more important than low prices and web presence as online customers are provided with more product or service choices with reduced costs. The perceived service quality includes guarantees customized services and performance of delivery (Doney and Cannon, 1997), warranties (Grazioli and Jarvenpaa, 2000) provided by the company (Kim et al., 2004). In order to deliver quality service online, companies need to understand the perception of customers regarding the quality of their services and the way the customer evaluate them.

Electronic service quality is broadly defined as the entire stages of a customer's interactions with
Internet website. In other words, it is the level to which Internet website enables effective and efficient purchasing, shopping and delivery (Zeithaml et al., 2000). Santos (2003) studied e-service quality and found that e-service quality is a measurement of the extensive customer judgment and assessment of the delivery of online service in the virtual marketplace. The significance of e-service delivery is acknowledged in the business world and among the reasons for the increase of these services over the Internet is the fact that it is much easier for customers to make a comparison between varying service offerings in contrast to traditional ways (Santos, 2003).

Excellent e-service quality is an important matter for online vendor. It is the factor that will enable them to attract more online customers. Lee and Lin (2005) noted that online customers expect higher levels of electronic service quality than customers in the traditional environment do. Cai and Jun (2003) revealed a positive and strong correlation between online vendors' service quality and their customer satisfaction.

Corresponding Author: Mohammad Al-Nasser, School of Business Management, College of Business, University Utara Malaysia, Malaysia 
Researchers have called for an in-depth analysis of the links between service quality and its outcomes (Rust and Oliver, 1994), because these links are not simple and direct (Brady et al., 2005). A widespread investigation of the complicated interrelationships will be useful for a complete understanding of the process that will result in favorable relational outcomes based upon web-based service quality. Furthermore studies that have validated by trial and error the link between traditional service quality and some outcomes such as customer satisfaction (Cronin et al., 2000), trust (Sharma and Patterson, 1999) were primarily conducted in the context of offline services.

However, even with the increased acknowledgement of online services, issues such as how online services quality is defined, its measurement and its determinants are still unresolved (Kenova and Jonasson, 2006). The development of e-commerce in both global and regional markets has led to the creation of special interest in the measurement of e-service quality and the examination of the e-service dimensions (Mekovec et al., 2007). Considerable studies have been conducted focusing on the measurement and evaluation of online service quality. Authors have developed different scales to evaluate online service quality.

Service quality may be defined as the difference between customers' perceptions of the service received and their expectations about service performance prior to the service offering (Asubonteng et al., 1996). If service performance does not meet expectations, people will think that the service quality low. However, when performance goes over expectations, the perception of the service quality is higher (Connolly, 2007). Therefore, customers' expectations are crucial in evaluating service quality. In addition, Asubonteng et al. (1996) found that when service quality increases, intentions to use the service or product and satisfaction increase.

E-service quality measurement in online shopping has been receiving increasing attention currently and as a result, many studies have tried to highlight major dimensions of e-service quality linked with online environment. These research works were conducted in different contexts such as e-service, online travel agency, online banking, online retailing, web portal, online public library and online shopping.

E-S-QUAL is commonly used in online service quality study. Kim et al. (2006) made use of it to measure online e-service quality measure to determine the main factors contributing to clients' satisfaction. The E-S-QUAL may be utilized along with E-RecS-QUAL scale, which measures the quality of recovery service offered by the site. The E-RecS-QUAL scale has the dimensions of responsiveness, compensation and contact to deal with customer issues or inquiries (Mekovec et al., 2007).

\section{MATERIALS AND METHODS}

A survey approach has been widely used in marketing research to obtain raw data from large groups of people (Cooper and Schindler, 2013). Babbie (2004) found that a survey is the tool most often used as a strategy in business and social researches. The major advantages of employing a survey include: the ability to collect data from large sample sizes at relatively low costs; the capability to identify factors related to the context of issue; and to measure perception and behavior by using relevant instruments (e.g., Likert scale) (Hair et al., 2000). A survey also allows collection of standardized common data as respondents give answers to the same fixed-response questions that allow direct comparisons between responses. This fixed-pattern of responses can facilitate the use of statistical analyses. Thus, a survey is considered the most appropriate data collection method for this study.

Hair et al. (2000) suggested that the choice of survey methods tends to vary according to several factors, which are usually based on the type of data required (e.g., quantitative, qualitative), the budget of available resources, the completion time frame and the requirement of quality data (e.g., generalization). As this study aims to make predictions about consumers' attitude and given the context of this study, quantitative data collected via survey seemed to be the most optimum and suitable method to use.

\subsection{E-SQ Measurement Instrument}

The dominating and most widely utilized scale for the assessment of service quality is SERVQUAL, developed by Parasuraman et al. (1985). It has 97 items in a total of 10 dimensions of service quality (Parasuraman et al., 1985). In 1988, the authors brought down the dimensions from 10 to 5 and the items from 97 to 22 . The dimensions comprise tangibles that include physical facilities, functional appeal and employee appearance; reliability that includes the ability to conduct promised service in an accurate manner and in a trustworthy way; assurance including personnel recognition that encourages user confidence and trust; and, lastly, empathy that includes care provision and paying individual attention to customers. From that time, the five service quality dimensions have become the basis for universal service quality measurement (Yang and Jun, 2002). 
Table 1. E-service quality measurements

\begin{tabular}{lllll}
\hline Construct & Authors & Dimensions & Coefficient alpha & No. of items \\
\hline E-service quality & Parasuraman et al. (2005) & Efficiency & 0.94 & 8 \\
(E-S-QUAL scale) & & System availability & 0.83 & 4 \\
& & Fulfillment & 0.89 & 7 \\
E-service quality & Privacy & 0.83 & 3 \\
(E-RecS-QUAL scale) & & Responsiveness & 0.88 & 5 \\
& & Compensation & 0.77 & 3 \\
\hline
\end{tabular}

Table 2. E-service quality items

\begin{tabular}{|c|c|}
\hline \multicolumn{2}{|l|}{ Efficiency } \\
\hline 1 & The e-retailer website makes it easy to find what I need. \\
\hline 2 & It makes it easy to get anywhere on the e-retailer website. \\
\hline 3 & It enables me to complete a transaction quickly on the e-retailer website. \\
\hline 4 & Information at the e-retailer website is well organized. \\
\hline 5 & It loads its pages fast. \\
\hline 6 & The e-retailer website is simple to use \\
\hline 7 & The e-retailer website enables me to get on to it quickly. \\
\hline 8 & This site is well organized. \\
\hline \multicolumn{2}{|c|}{ System availability } \\
\hline 9 & The e-retailer website is always available for business. \\
\hline 10 & The e-retailer website launches and runs right away. \\
\hline 11 & The e-retailer website does not crash. \\
\hline 12 & Pages at this site do not freeze after I enter my order information. \\
\hline \multicolumn{2}{|l|}{ Fulfillment } \\
\hline 13 & E-retailer website delivers orders when promised. \\
\hline 14 & E-retailer website makes items available for delivery within a suitable time frame. \\
\hline 15 & E-retailer website quickly delivers what I order. \\
\hline 16 & E-retailer website sends out the items ordered. \\
\hline 17 & E-retailer website has in stock the items the company claims to have. \\
\hline 18 & E-retailer website is truthful about its offerings. \\
\hline 19 & E-retailer website makes accurate promises about delivery of products. \\
\hline \multicolumn{2}{|l|}{ Privacy } \\
\hline 20 & E-retailer website protects information about my Web-shopping behaviour. \\
\hline 21 & E-retailer website does not share my personal information with other websites. \\
\hline 22 & E-retailer website protects information about my credit card. \\
\hline \multicolumn{2}{|c|}{ Responsiveness } \\
\hline 23 & E-retailer website provides me with convenient options for returning items. \\
\hline 24 & E-retailer website handles product returns well. \\
\hline 25 & E-retailer website offers a meaningful guarantee. \\
\hline 26 & E-retailer website tells me what to do if my transaction is not processed. \\
\hline 27 & E-retailer website takes care of problems promptly. \\
\hline \multicolumn{2}{|c|}{ Compensation } \\
\hline 28 & E-retailer website compensates me for problems it creates. \\
\hline 29 & E-retailer website compensates me when what I ordered doesn't arrive on time. \\
\hline 30 & E-retailer website picks up items I want to return from my home or business. \\
\hline \multicolumn{2}{|l|}{ Contact } \\
\hline 31 & E-retailer website provides a telephone number to reach the company. \\
\hline 32 & E-retailer website has customer service representatives available online. \\
\hline 33 & E-retailer website offers the ability to speak to a live person if there is a problem. \\
\hline
\end{tabular}


Boshoff (2007) conducted an assessment of the psychometric nature of E-S-QUAL and reported it to be an instrument that is valid and reliable. It appears to be the most effective scale created to gauge e-service quality in the current times. On the basis of the above discussion, the researcher adopted Parasuraman et al. (2005) E-S-QUAL four dimensions and E-RecS-QUAL three dimensions. Table 1 shows the dimensions and reliability of each dimension as stated by Parasuraman et al. (2005) Moreover, Table $\mathbf{2}$ shows e-service quality dimensions and items used. The general E-S-QUAL scale consists of 22 items with four dimensions, which are efficiency, fulfillment, system availability and privacy. The second scale is appropriate for customers who do not frequently avail of the sites' services and it consists of 11 times with three dimensions, which are responsiveness, compensation and contact.

E-service quality is measured in this study by a Likertscaled instrument. A seven-point Likert scale is often utilized to examine e-service quality which is selected based on its benefit of enabling intercultural questioning while avoiding systematic errors (Lee and Turban, 2001).

\section{RESULTS}

\subsection{Normality}

Normality is the most fundamental assumption in multivariate analysis (Hair et al., 2010). It measures whether differences revealed between the obtained and predicted scores of dependent variables (Stewart, 1981). The study sample was taken from the population, it is crucial to compare the sample normal distribution to one of the basic social science measurements, namely, the normal distribution of the population.

In the present study, the entire variables were tested for normality where the values of skewness and kurtosis were examined to test the scores of normality. Table 3 showed that the overall the values of skewness and kurtosis were within the critical value. Hence, the possibility of issues surrounding non-normal distribution appeared to be insignificant.

\subsection{E-Service Quality}

According to Asubonteng et al. (1996), e-service quality is, the difference between customers' expectations for service performance prior to the service encounter and their perceptions of the service received. On the other hand, Bitner et al. (1990) defined it as "the consumers' overall impression of the relative inferiority/superiority of the organization and its services. These definitions vary from person to person but their essence is similar (Khalil, 2011). Ojo (2010) stated that the definition of service quality differs only in their wording but they generally relate to the determination of whether perceived service delivery leads to the meeting, exceeding, or failure to satisfy customer expectations.

Parasuraman et al. (2005) defined e-service quality and proposed a new method for its measurement, which is E-S-QUAL. The measurement consists of four dimensions with 22 items. These dimensions are fulfillment, efficiency, privacy and system availability. Accompanying this main scale is a subscale referred to as E-RecS-Qual, formulated for customers facing issues while using online services. This subscale comprises three dimensions of responsiveness, compensation and contract and has 11 items. Two scales have undergone reliability and validity tests and shown good psychometric characteristics. Later, Parasuraman et al. (2005) tested it in online shopping contexts. The efficiency dimension is concerned with the ease of speed and access and utilization of the site. It is referred to as the capability of the customers to use the site, find their products of choice and all the associated information with minimal effort. Meanwhile the system availability dimension relates to the technical function of the site and is related to the technical functioning and the level to which the site is available and functioning properly.

E-S-QUAL is commonly used in online service quality studies. Kim et al. (2006) made use of it to measure online e-service quality measure to determine the main factors contributing to clients' satisfaction. The E-S-QUAL may be utilized along with E-RecS-QUAL scale, which measures the quality of recovery service offered by the site. The E-RecS-QUAL scale has the dimensions of responsiveness, compensation and contact to deal with customer issues or inquiries (Mekovec et al., 2007). This method is the basis of the e- services quality evaluation approaches.

\subsection{Reliability of Measures}

Reliability refers to whether or not the measurement scale is characterized by consistency and stability. A research instrument's reliability is defined as the concerns to the degree to which the instrument produces the same results in repeated cases (Carmines and Zeller, 1979). It presents the level to which the respondent answers the same or similar questions consistently every time (Cronbach, 1951). It is the function that a researcher should consider as a fundamental requirement prior to proceeding with the data analysis and interpretation. Reliability is confirmed as a necessary target that is considered as a validity criterion (Crocker and Algina, 1986). 
Table 3. Normality test

\begin{tabular}{llllll}
\hline & $\mathrm{N}$ & Mean & Std. Deviation & Skewness & Kurtosis \\
\hline Attitude & 414 & 4.78 & 1.35 & -0.500 & -0.70 \\
Risk & 414 & 4.72 & 1.54 & -0.500 & -0.75 \\
Trust & 414 & 3.50 & 1.36 & 0.270 & -0.66 \\
E-sq & 414 & 3.52 & 1.43 & 0.500 & -0.60 \\
Culture & 414 & 3.47 & 1.09 & 0.005 & -0.24 \\
\hline
\end{tabular}

Table 4. Reliability for study’s variables

\begin{tabular}{|c|c|c|c|c|c|c|}
\hline Construct & Instrument & Dimensions & $\begin{array}{l}\text { Original } \\
\text { alpha }\end{array}$ & $\begin{array}{l}\text { Alpha } \\
\text { (pilot test) }\end{array}$ & $\begin{array}{l}\text { Alpha } \\
\text { (main sample) }\end{array}$ & $\begin{array}{l}\text { No. } \\
\text { of items }\end{array}$ \\
\hline \multirow{7}{*}{$\begin{array}{l}\text { E-service quality } \\
\text { (E-S-QUAL Scale) } \\
\text { E-service quality } \\
\text { (E-RecS-QUAL Scale) }\end{array}$} & \multirow[t]{7}{*}{ Parasuraman et al. (2005) } & Efficiency & 0.94 & 0.852 & 0.972 & 8 \\
\hline & & System availability & 0.83 & 0.608 & 0.886 & 4 \\
\hline & & Fulfillment & 0.89 & 0.713 & 0.941 & 7 \\
\hline & & Privacy & 0.83 & 0.874 & 0.941 & 3 \\
\hline & & Responsiveness & 0.88 & 0.890 & 0.904 & 5 \\
\hline & & Compensation & 0.77 & 0.796 & 0.796 & 3 \\
\hline & & Contact & 0.81 & 0.903 & 0.897 & 3 \\
\hline
\end{tabular}

Table 5. Factor analysis of e-service quality

\begin{tabular}{|c|c|c|c|c|}
\hline Factor & Factor & Eigen & Variance explained & Alpha \\
\hline Dimension ONE & loading & 21.74 & 65.9 & 0.984 \\
\hline It makes it easy to get anywhere on the e-retailer website & 0.908 & & & \\
\hline The e-retailer website makes it easy to find what I need. & 0.906 & & & \\
\hline The e-retailer website is simple to use. & 0.895 & & & \\
\hline E-retailer website sends out the items ordered. & 0.885 & & & \\
\hline The e-retailer website is always available for business. & 0.883 & & & \\
\hline It enables me to complete a transaction quickly on the e-retailer website. & 0.881 & & & \\
\hline The e-retailer website enables me to get on to it quickly. & 0.880 & & & \\
\hline The e-retailer website launches and runs right away. & 0.874 & & & \\
\hline Information at the e-retailer website is well organized. & 0.870 & & & \\
\hline E-retailer website protects information about my Web-shopping behavior. & 0.796 & & & \\
\hline E-retailer website is truthful about its offerings. & 0.776 & & & \\
\hline E-retailer website makes items available for delivery within a suitable time frame. & 0.768 & & & \\
\hline This site is well organized. & 0.766 & & & \\
\hline E-retailer website does not share my personal information with other web sites. & 0.746 & & & \\
\hline It loads its pages fast & 0.744 & & & \\
\hline E-retailer website makes accurate promises about delivery of products. & 0.737 & & & \\
\hline E-retailer website has in stock the items the company claims to have. & 0.732 & & & \\
\hline E-retailer website delivers orders when promised. & 0.729 & & & \\
\hline E-retailer website quickly delivers what I order & 0.721 & & & \\
\hline E-retailer website protects information about my credit card. & 0.713 & & & \\
\hline E-retailer website provides a telephone number to reach the company. & 0.691 & & & \\
\hline The e-retailer website does not crash. & 0.689 & & & \\
\hline E-retailer website tells me what to do if my transaction is not processed. & 0.684 & & & \\
\hline Pages at this site do not freeze after I enter my order information. & 0.626 & & & \\
\hline Dimension TWO & loading & 2.582 & 73.7 & 0.941 \\
\hline E-retailer website picks up items I want to return from my home or business. & 0.821 & & & \\
\hline E-retailer website compensates me when what I ordered doesn't arrive on time. & 0.812 & & & \\
\hline E-retailer website handles product returns well. & 0.808 & & & \\
\hline E-retailer website provides me with convenient options for returning items. & 0.785 & & & \\
\hline E-retailer website compensates me for problems it creates. & 0.785 & & & \\
\hline E-retailer website offers a meaningful guarantee. & 0.708 & & & \\
\hline E-retailer website takes care of problems promptly. & 0.674 & & & \\
\hline E-retailer website offers the ability to speak to a live person if there is a problem & 0.644 & & & \\
\hline E-retailer website has customer service representatives available online. & 0.581 & & & \\
\hline
\end{tabular}


An instrument of data collection is considered reliable when it provides consistent results every time it is used on the same sample or a different sample from the same target population (Tull and Albaum, 1973). In addition, based on Fraenkel et al. (2011), an instrument is deemed reliable if it provides similar results; in other words, it is a measure of precision. Sekaran and Bougie (2010) stated that reliability coefficient is better if it is closer to 1.00. Generally, while the acceptable alpha coefficient should be higher than 0.7 , a coefficient of 0.6 is still considered acceptable (Bagozzi and $\mathrm{Yi}, 1988$ ). Collis and Hussey (2009) suggested the following rule of thumb: a Cronbach's alpha coefficient that is 0.70 or higher denotes a good internal reliability measure, while those ranging between 0.50 and 0.69 denote an acceptable level of reliability and those less than 0.50 are deemed poor. For a value of 0.50 or higher denotes an acceptable level of reliability.

Two measures are used to evaluate reliability namely Cronbach's alpha $(\alpha)$ and item-to-total correlation. Cronbach's alpha, is described as a measure that provides an idea as to the internal consistency by presenting the way items are used to measure some constructs of interest by examining the proportion of times variance compared to common known figures. Cronbach's alpha is considered high if the correlation between particular items increases. Items having low correlation values should be eliminated under particular conditions as they might lessen the total relationship value within a single set of items; in other words, low correlation value items are invalid to use. Robinson et al. (1991) contended that any correlation value ranging from 0.50 to 0.60 displays satisfactory reliability, while those ranging from 0.60 to 0.70 display an accepted reliability. Finally, those over 0.70 display very good reliability.

This purification of scales involved calculating the alpha scores of every scale and deleting indicators having low reliability when they were deemed as not representing a distinct and significant theoretical dimension (Moorman et al., 1992; Pritchard et al., 1999). In the present study, the reliability of the instruments used was examined using Cronbach's alpha. Generally, the measurement scales showed good performance with Cronbach's alpha values higher than 0.7 for all measurement constructs, However; most of the measurement scales in this study showed excellent performance with Cronbach's alpha values more than 0.9. Refer to Table 4 for the result.

\subsection{Factor Analysis of E-service Quality on Online Shopping}

The e-service quality items were exposed to an explanatory factor analysis. The analysis of the items was carried out on the data set from the responses showed a two-factor solution. The two-factor solution explained $73 \%$ of the variance. Procedures of principal component and varimax were utilized to determine the dimensions of orthogonal factor. The latent criterion of 1.0 was used for factor extraction while factor loadings of 0.40 were used for item inclusion (Hair et al., 1995).

The factor's composite reliability for each construct was studied to test the indicators internal consistency measuring the underlying factors (Fornell and Larcker, 1981). Netemeyer et al. (2003) suggested that a factor is reliable when its composite reliability is higher than 0.60. The Cronbach's alpha for the four dimensions ranged from acceptable to very good. Specifically, the Cronbach's alpha coefficients for the first dimension and second dimension were 0.984 and 0.941 , respectively, were seen to have a very good reliability. The reliability of these statements was regarded as being good and can therefore produce consistent results in repetitive tests. The Cronbach's alpha coefficients for each dimension of e-service quality are depicted Table 5.

\section{DISCUSSION}

\subsection{E-Service Quality and Consumer Trust}

The present study revealed that the proposed relationship between e-service quality and consumer trust was statistically significant. The correlation coefficient of the effect of perceived service quality and consumer trust was high, suggesting that e-service quality strongly and positively affected consumer trust in Internet shopping. People who are likely to attach great importance to service quality tend to show trust in online shopping. Such finding is consistent with prior findings concerning the positive relationship between e-service quality and consumer trust (Chen, 2006; Zhou, 2011). However, the finding is inconsistent with previous studies that showed no relationship between e-service quality and consumer trust (Shu-Chiung et al., 2011).

According to Zeithaml et al. (2000), service quality in online shopping is a significant strategy to achieve success, even more than low prices and web presence. Alsajjan et al. (2006) found that e-service quality is a prominent variable in literature dedicated to trust. Harris and Goode (2004) revealed a correlation between e-service quality and determinants 
of trust. Service quality reflects the idea of customers comparing their expectations concerning the performance of service (Gronroos, 1984).

The theoretical relationship between service quality and trust has been advocated by several research studies in different ways. For example, Chuang and Fan (2011) found that service quality determined trust and that service quality delivered by e-retailer that satisfied customer's expectations encouraged trust belief. Zhou et al. (2010) also revealed that service quality significantly affected trust. For Wakefield et al. (2004), quality of service can develop the initial trust of consumers, but the absence of service quality may prevent them from being satisfied and from trusting the service provider. In another study conducted by Martin and Camarero (2008), they found that service quality also influenced trust; but it only did so indirectly through satisfaction.

Phung et al. (2009) revealed that electronic service quality had a positive and significant impact on consumer's trust on an online company. Alsajjan and Dinnes (2010) examined trust construct by employing a revised model to examine customer's acceptance of ebanking. Data was gathered from the U.K. and Saudi Arabia. Results revealed that e-service quality did not influence attitude directly for both groups. In addition, trust was a full mediator of the effect of service quality on behavioral intention.

Shu-Chiung et al. (2011) studied e-service quality in Malaysia and Taiwan. They found that in the context of Taiwan, e-service quality had significant impact on satisfaction and trust but the e-service quality of Malaysia model had significant effects on satisfaction but not on trust. Chen (2006) revealed that service quality and overall satisfaction significantly influenced a consumer's overall trust in a website. In addition, based on study, quality of service was expected to affect customer trust in cases where the service provider has been associated with the customer for a significant time. However, they revealed that not all service quality dimensions reflected the same contribution to trust.

Fassnacht and Kose (2006) in their study to link Web-based service quality to customer satisfaction, trust and loyalty found contrasting results from previous studies when they revealed no significant direct effect of e-service on trust. They observed significant indirect effects, which indicate that a considerable level of impact was mediated by variables.

\section{CONCLUSION}

This study discussed the literature review concerning consumer attitude toward online shopping upon the Internet, along with consumer e-service quality, trust and risk. Cultural issues of service quality perceptions were also discussed. The attitude toward online shopping model that emphasizes the relationships between e-service quality, culture, trust and risk was presented in this study.

The findings revealed that service quality was relatively significant in its impact on consumer trust in online shopping, proving the proposed positive direct impact of perceived service quality upon customer trust. However, perceived risk was revealed to be linked with consumer trust towards online shopping, contrary to the proposed hypothesis. According to the results, trust in online retailer was positively associated with the attitude of consumers to online shopping. Therefore, marketers and managers should take into close consideration the requirements of trust development in online retailing. Finally, trust based on e-service quality is considered as the most suitable environment for developing favorable consumer attitude towards online shopping. The findings indicated that in order to design strategies for effective service delivery and customer service expectation, the cultural background of consumers should be understood.

\section{REFERENCES}

Alsajjan, A., B. Bander and C. Dennis, 2006. The impact of trust on acceptance of online banking. Proceedings of the European Association of Education and Research in Commercial Distribution, Jun. 27-30, Brunel University, West London.

Alsajjan, B. and C. Dennis, 2010. Internet banking acceptance model: Cross-market examination. J. Bus. Res., 63: 957-963. DOI: 10.1016/j.jbusres.2008.12.014

Asubonteng, P., K.J. McCleary and J.E. Swan, 1996. SERVQUAL revisited a critical review of service quality. J. Services Market., 10: 62-81. DOI: $10.1108 / 08876049610148602$

Babbie, E.R., 2004. The practice of Social Research. 10th Edn., Wadsworth Thomson Learning, Belmont, CA.

Bagozzi, R.P. and Y. Yi, 1988. On the evaluation of structural equation models. J. Acad. Market. Sci., 16: 74-94. DOI: $10.1007 / \mathrm{BF} 02723327$

Bitner, M.J., B.H. Booms and M.S. Tetreault, 1990. The service encounter: Diagnosing favorable and unfavorable incidents. J. Market., 54: 71-84. DOI: $10.2307 / 1252174$ 
Boshoff, C., 2007. A psychometric assessment of E-SQUAL: A scale to measure electronic service quality. J. Electr. Commerce Res., 8: 101-114.

Brady, M.K., G.A. Knight, J.J. Cronin, G.T.M. Hult and B.D. Keillor, 2005. Removing the contextual lens: A multinational, multi-setting comparison of service evaluation models. J. Retail., 81: 215-230. DOI: 10.1016/j.jretai.2005.07.005

Cai, S. and M. Jun, 2003. Internet users' perceptions of online service quality: A comparison of online buyers and information searchers. Manag. Service Q., 13: 504-519. DOI: 10.1108/09604520310506568

Carmines, E.G. and R.A. Zeller, 1979. Reliability and Validity Assessment. 1st Edn., Sage Publications, Beverly Hills, CA., ISBN-10: 0803913710, pp: 70.

Chen, C., 2006. Identifying significant factors influencing consumer trust in an online travel site. Inform. Technol. Tourism, 8: 197-214. DOI: 10.3727/109830506778690849

Chuang, H.M. and C.J. Fan, 2011. The mediating role of trust in the relationship between e-retailer quality and customer intention of online shopping. Afr. J. Bus. Manage., 5: 9522-9529.

Collis, J. and R. Hussey, 2009. Business Research: A Practical Guide for Undergraduate and Postgraduate Students. 3rd Edn., Palgrave Macmillan, New York, ISBN-10: 1403992479, pp: 420.

Connolly, R., 2007. Factors influencing Irish consumers' trust in internet shopping: management research news: Communication of emergent international managementresearch, 31, 5 consumer perceptions. Electr. Commerce Res. Applic., 2: 203215.

Cooper, D. and P. Schindler, 2013. Business Research Methods. 1st Edn., McGraw-Hill Higher Education, New York, ISBN-10: 0077774434.

Crocker, L.M. and J. Algina, 1986. Introduction to Classical and Modern Test Theory. 1st Edn., Holt, Rinehart and Winston, New York, pp: 527.

Cronbach, L.J., 1951. Coefficient alpha and the internal structure of tests. Psychometrika, 16: 297-334. DOI: $10.1007 / \mathrm{BF} 02310555$

Cronin, J.J., M. Brady and G.T.M. Hult, 2000. Assessing the effects of quality, value and customer satisfaction on consumer behavioral intentions in service environments. J. Retail., 76: 193-218. DOI: 10.1016/S0022-4359(00)00028-2

Doney, P. and J. Cannon, 1997. An examination of the nature of trust in buyer-seller relationships. J. Market., 61: 35-51. DOI: 10.2307/1251829
Fassnacht, M. and I. Kose, 2006. Quality of electronic services: Conceptualizing and testing a hierarchical model. J. Service Res., 9: 19-37. DOI: $10.1177 / 1094670506289531$

Fornell, C. and D. Larcker, 1981. Evaluating structural equations models with unobservable variables and measurement error. J. Market. Res., 18: 39-50. DOI: $10.2307 / 3151312$

Fraenkel, J.R., N. Wallen and H. Hyun, 2011. How to Design and Evaluate Research in Education. 8th Edn., McGraw-Hill Education, Boston, ISBN-10: 0078097851, pp: 704.

Grazioli, S. and S. Jarvenpaa, 2000. Perils of internet fraud: An empirical investigation of deception and trust with experienced internet consumers. IEEE Trans. Syst. Man Cybernetics, 30: 395-410. DOI: $10.1109 / 3468.852434$

Gronroos, C., 1984. A service quality model and it is marketing implications. Eur. J. Market., 18: 36-44. DOI: 10.1108/EUM0000000004784

Hair, J.F., C.W. Lamb and C.D. McDaniel, 2000. Marketing. 1st Edn., South-Western Publishing, Cincinnati, Ohio.

Hair, J.F., R.E. Anderson, W.C. Black and R.L. Tatham, 1995. Multivariate Data Analysis: With Readings. 4th Edn., Macmillian Publishing Company, New Jersey, ISBN-10: 0023490209, pp: 500.

Hair, J.F., W.C. Black, B.J. Babin and R.E. Anderson, 2010. Multivariate Data Analysis: A Global Perspective. 7th Edn., Pearson Education, New Jersey, ISBN-10: 0135153093, pp: 800.

Harris, L.C. and M.M. Goode, 2004. The four levels of loyalty and the pivotal role of trust: A study of online service dynamics. J. Retail., 80: 139-158. DOI: $10.1016 /$ j.jretai.2004.04.002

Kenova, V. and P. Jonasson, 2006. Quality Online Banking Services. Doctoral Dissertation, Jönköping University.

Khalil, K.M., 2011. Online service quality and customer satisfaction: A case study of Bank Islam Malaysia Berhad.

Kim, J.W., J. Choi, W. Qualls and J. Park, 2004. The Impact of CRM on firm-and relationship-level performance in distribution networks. Commun. Assoc. Inform. Syst., 14: 632-652.

Kim, M., J.H. Kim and S. Lennon, 2006. Online service attributes available on apparel retail web sites: An E-S-QUAL approach. Manag. Service Q., 16: 51-77. DOI: 10.1108/09604520610639964

Lee, G.G. and H.F. Lin, 2005. Customer perceptions of e-service quality in online shopping. Int. J. Retail Distribution Manag., 33: 161-176. DOI: $10.1108 / 09590550510581485$ 
Lee, M.K.O. and E. Turban, 2001. A trust model for consumer internet shopping. Int. J. Electr. Commerce, 6: 75-91.

Martin, S.S. and C. Camarero, 2008. Consumer trust to a web site: Moderating effect of attitudes toward online shopping. Cyber. Psychol. Behav., 11: 549554. DOI: $10.1089 / \mathrm{cpb} .2007 .0097$

Mekovec, R., G. Bubas and N. Vrcek, 2007. A method for improvement of objectivity of e-service quality evaluation. J. Inform. Organ. Sci., 31: 15-27.

Moorman, C., G. Zaltman and R. Deshpande, 1992. Relationships between providers and users of market research: The dynamics of trust. J. Marketing Res., 29: 314-28. DOI: $10.2307 / 3172742$

Netemeyer, R.G., W.O. Bearden and S. Sharma, 2003. Scaling Procedures: Issues and Applications. 1st Edn., Sage Publications, Oaks, CA., ISBN-10: 0761920277, pp: 224.

Ojo, O., 2010. The relationship between service quality and customer satisfaction in the telecommunication industry: Evidence from Nigeria. BRAND. Broad Res. Account. Negotiation Distribut., 1: 88-100.

Parasuraman, A., V.A. Zeithaml and A. Malhotra, 2005. E-S-Qual: A multiple-item scale for assessing electronic service quality. J. Service Res., 7: 213233. DOI: $10.1177 / 1094670504271156$

Parasuraman, A., V.A. Zeithaml and L.L. Berry, 1985. A conceptual model of service quality and its implications for future research. J. Market. Fall, 49: 41-50. DOI: $10.2307 / 1251430$

Phung, K.D., K.L. Yen and M.H. Hsiao, 2009. Examining the factors associated with consumer's trust in the context of business-to-consumer ecommerce. Proceedings of the IEEE International Conference on Industrial Engineering and Engineering Management, Dec. 8-11, IEEE Xplore Press, Hong Kong, pp: 2241-2245. DOI: 10.1109/IEEM.2009.5373073

Pritchard, M.P., M.E. Havitz and D.R. Howard, 1999. Analyzing the commitment-loyalty link in service contexts. J. Acad. Market. Sci., 27: 333-348. DOI: 10.1177/0092070399273004

Robinson, J.P., P.R. Shaver and L.S. Wrightsman, 1991. Measures of Personality and Social Psychological Attitudes. 1st Edn., Academic Press, ISBN-10: 0125902441, pp: 753.

Rust, R.T. and R.L. Oliver, 1994. Service Quality: Insights and Managerial Implications from the Frontier. SAGE Publications, Inc.
Santos, J., 2003. E-service Quality: A model of virtual service quality dimensions. Manag. Service Q., 131: 233-246. DOI: 10.1108/09604520310476490

Sekaran, U. and R. Bougie, 2010. Research Methods for Business: A Skill Building Approach. 5th Edn., John Wiley and Sons, Chichester, ISBN-10: 0470744790, pp: 488.

Sharma, N. and P.G. Patterson, 1999. The impact of communication effectiveness and service quality on relationship commitment in consumer, professional services. J. Services Market., 13: 151-170. DOI: 10.1108/08876049910266059

Shu-Chiung, L., L. Sheng-Wei, T. Chin-Yen, Y. YingPing and Y. Pei-Hwa, 2011. How E-servqual affects customer's online purchase intention through crossculture comparison? Proceedings of the Technology Innovation and Industrial Management, Sept. 14-14, Oulu, Finland.

Stewart, D.W., 1981. The application and misapplication of factor analysis in marketing research. J. Market. Res., 18: 51-62.

Tull, D.S. and G.S. Albaum, 1973. Survey Research: A Decisional Approach. 1st Edn., Intent Educational Publishers, New York, ISBN-10: 070022436X, pp: 244.

Wakefield, R.J., M.H. Stocks and W.M. Wilder, 2004. The role of web site characteristics in initial trust formation. J. Comput. Inform. Syst., 45: 94-103.

Yang, Z. and M. Jun, 2002. Consumer perception of eservice quality: From internet purchaser and nondevelopment and managerial implications. J. Bus. Strategies, 19: 19-41.

Zeithaml, V.A., A. Parasuraman and A. Malhotra, 2000. A Conceptual Framework for Understanding e-Service Quality: Implications for Future Research and Managerial Practice. 1st Edn., Marketing Science Institute, Cambridge, MA., pp: 46.

Zhou, T., 2011. Examining the critical success factors of mobile website adoption. Online Inform. Rev., 35: 636-652. DOI: 10.1108/14684521111161972

Zhou, T., Y. Lu and B. Wang, 2010. Integrating TTF and UTAUT to explain mobile banking user adoption. Comput. Hum. Behav., 26: 760-767. DOI: 10.1016/j.chb.2010.01.013 